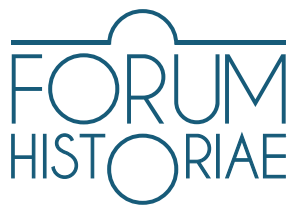

\title{
Building and Testing Trust Within a Socialist Dictatorship: The Case of Czechoslovak Experts in Africa Pre- and Post-1968
}

\author{
Barbora Buzássyová
}

\begin{abstract}
BUZÁSSYOVÁ, BARBORA. Building and Testing Trust Within a Socialist Dictatorship: The Case of Czechoslovak Experts in Africa Pre- and Post- 1968.

This article explores the foundations of trust between Czechoslovak state bodies and experts selected for foreign service in Africa. The focus is on the means through which this trust was challenged during long periods of separation from socialist ways of life, ways which were reinvented after the systemic political changeover in Czechoslovak administration after August 1968. Drawing on the concept of "navigation", it examines the strategies experts developed to earn and restore credibility in the eyes of party authorities after the total disintegration of prior networks of trust following the Warsaw Pact invasion of Czechoslovakia. During their tenure abroad, experts established trust networks on various levels - not only with Czechoslovak political representatives, but also with other experts in common agencies and even officers of the Czechoslovak Intelligence Service. These personal ties proved to be instrumental for negotiating future career prospects after the stormy years of 1968-1969. However, contrary to popular belief, this article demonstrates that it was less political attitude and more the economic potential of the experts' international positions that determined their ongoing credibility as "honoured" citizens.
\end{abstract}

Keywords: Czechoslovakia, experts, credibility, socialism, trust network, Africa

DOI: https://doi.org/10.31577/forhist.2021.15.2.6

$\mathrm{H}$ ow were the networks of trust between citizens and state authorities developed and maintained under a socialist dictatorship? Scholars have established the considerable significance of trust, or lack thereof, in the function of socialist regimes and mobilization popular support. ${ }^{1}$ However, these works have mostly focused on the strategies of renegotiating social contracts between the state and society after the fall of Stalinism, which subsequently helped to stabilize the Eastern European region. In general, communities of trust can be defined as social networks which unite people through shared interests, though the concept of trust usually carries with it a number of inherent characteristics. For instance, Russian historian Alexey Tikhomirov offers the following insights into the notion of trust: it stabilizes relationships and simplifies the social environment; it is the foundation of reciprocity and cooperation based on

This study is freely based on the final chapter of the author's dissertation: Socialist Internationalism in Practice: Shifting Patterns of the Czechoslovak Educational Aid Programmes to Sub-Saharan Africa, 1961-1989. Bratislava : Comenius University, 2021.

The study was supported by the Slovak Research and Development Agency under the contract No. APVV-200333 Crossing the Frontiers. The Phenomenon of Mobility in the History of Slovakia.

1 JONES, Polly. Dilemmas of De-Stalinization. Negotiating Cultural and Social Change in the Khrushchev Era. London: Routledge, 2006; CROWLEY, David - REID, E. Susan (eds). Pleasures in Socialism: Leisure and Luxury in the Eastern Bloc. Evanston : Northwestern University Press, 2010; SCHATTENBERG, Susanne. Trust, Care and Familiarity in the Politburo. Brezhnev's Scenarios of Power. In Kritika: Explorations in Russian and Euroasian History, 2015, vol. 16, no. 4, p. 835-858. 
a balance of rights and duties; and it is a resource for collective action, which plays a crucial role in defining friends and enemies, negotiating status or inequalities and outlining the moral and immoral patterns of daily life. ${ }^{2}$ With this in mind, he coined the term "socialist regimes of trust and distrust," in which the Communist Party played a leading role in defining, objectifying and distributing trust and distrust. The party instrumentalized the phenomena of trust and distrust as tools for managing its personnel policy and creating tension between ordinary people and "honoured" citizens-those who had already earned trust. ${ }^{3}$ The vernacular of trust and distrust thus allowed state authorities to instil ritualized social practices and develop a predictable behaviour for its citizens.

This phenomenon of "trusted" and "untrustworthy" is closely tied to wider scholarly discussions about the social dynamics between states and citizens in socialist dictatorships. Instead of dividing the most common reactions to ultimate control in to black and white categories of "true believers" (loyal) and "resisters" (disloyal), scholars have recently started

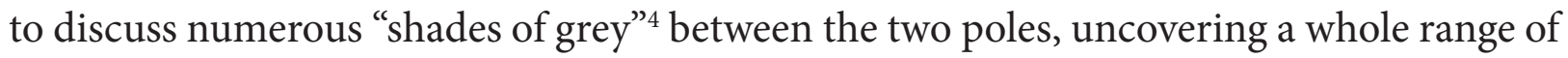
strategies through which people learned to survive under the least unfavourable terms, yet within the conditions dictated by the regime. Confronted with harsh restrictions and pervasive scarcity, people took their own initiatives to exploit opportunities - when available - for personal gain. German historian Alf Lüdtke, a leading figure of the Alltagsgeschichte, in an attempt to comprehend the everyday experience of factory workers in Nazi Germany termed this behaviour "navigation." "Navigation" defines the ways through which people learned to sidestep the rules in order to manage the world around them and reap some benefits from the difficult situation they found themselves in. ${ }^{6}$ Cooperation and compliance were often passports to normal life, with rewards and privileges reserved for those who conformed and an arduous path for those who did not. This brings us to the question of strategic loyalty; how citizens earned credibility from state authorities, how they exploited it to meet their own ends and how they re-established trust after political unrest. In light of such theoretical considerations, this study seeks to answer the following questions:

- What strategies did experts ${ }^{7}$ adopt in order to earn trust and credibility from official authorities - what experience and/or qualities supported their nomination to cadre reserves and were there any examples of deliberate manipulation?

- When dispatched as experts to countries outside the socialist bloc, how did they navigate through the newly-established web of relations-towards Czechoslovak intelligence service officers' requests for cooperation, towards their western and local colleagues and towards other members of the Czechoslovak community?

2 TIKHOMIROV, Alexey. The Grammar of Trust and Distrust under State Socialism after Stalin: An Introduction. In Journal of Modern European History, 2017, vol. 15, no. 3, p. 314-315.

3 TIKHOMIROV 2017, p. 320.

4 See CORNER, Paul. Dictatorship revisited: Consensus, coercion, and strategies of survival. In Modern Italy, 2017, vol. 22 , no. 4 , p. $435-444$.

5 LÜDTKE, Alf (ed.). The History of Everyday Life. Reconstructing Historical Experience and Ways of Life. Princeton : Princeton University Press, 1989.

6 See for instance GELLATELY, Robert. Backing Hitler: Consent and Coercion in Nazi Germany. Oxford : Oxford University Press, 2001; LIM, Jie-Hyun Lim. Coercion and Consent: A Comparative Study of "Mass Dictatorship". In Contemporary European History, 2004, vol. 13, no. 2, p. 249-252; CORNER, Paul (ed.). Popular Opinion in Totalitarian Regimes. Fascism, Nazism, Communism. Oxford : Oxford University Press, 2009.

7 This text understands experts as: individuals qualified in a certain area of expertise who were, by a decision of the Czechoslovak state authorities, sent abroad to participate in development-related projects for various African administrations. The focus is on experts in "top" positions, i.e. ministerial advisers, employees of UNESCO departments, and scientists and managers in scientific or educational institutions and industrial companies. 
- In what ways were these various types of loyalties and alliances expressed?

- Considering the shared experience of working abroad with all the privileges and obligations the foreign service was due, were there any examples of internal, "sub-loyalties" within expert groups that challenged the existing social contract with the Czechoslovak authorities?

- What happened to these networks of trust after Soviet suppression of the Prague Spring in August 1968?

- What strategies did experts develop to restore credibility in the eyes of the new leadership?

The study is divided into two main sections. The first part examines developments in the state management of expert service abroad through the 1960s and 1970s, focusing on the selection criteria and expectations of state bodies linked to the expert service. The next section centres on specific, micro-histories of former experts, examining particularly the circumstances of their nomination to the cadre reserves and their reactions to authorities' demands for the expression and performance of loyalty. As illustrated in the following paragraphs, the relationship between the subject and object of trust was not static, in which both actors behaved according to fixed rules. Instead, the power dynamics were ever-changing and relied on constant negotiation.

The expert service was a stable component of a broader system of technical development aid which the Czechoslovak government provided to countries of the Global South since the beginning of decolonisation in the mid-1950s. Nikita Khrushchev's appeal to "active foreign policy" freed Eastern European leaders from the constraints of Stalinist isolation and opened doors for various forms of East-South cooperation. In a commitment to the revived agenda of socialist solidarity, Czechoslovak authorities, led by President and First Secretary of the Central Committee of the Communist Party of Czechoslovakia (ÚV KSČ) Antonín Novotný, were keen to flatter the new African leaders and assist with the allaround development of post-colonial peoples. Expert services offered by Czechoslovak institutions to African leaders included a wide range of activities, from advisory positions at individual ministries to the posting of professors and lecturers to schools and universities. Technicians, researchers and industrial specialists were also sent to establish a scientific and industrial base for a "third world" economic take-off. Development aid programmes were thus considered not only a vital strategy in shaping the future political path of beneficiary administrations, but also as a gateway to further economic expansion of Czechoslovak-and more broadly Eastern European-industry to non-socialist markets.

During their tenure abroad, Czechoslovak experts developed relationships with other colleagues from their workplaces, either from the capitalist west or from the ranks of the local elite. Against this background, it comes as no surprise that many of them became targets of the Czechoslovak Intelligence Service (part of Czechoslovak State Security, the Státní bezpečnost or STB), who sought to uncover confidential information about political developments in Africa, or even better, about the financial agreements of African regimes with western firms. Czechoslovak experts abroad were subject to the $4^{\text {th }}$ department of the First Directory of the Ministry of Interior (counter-intelligence division), which administered official travels abroad, including cases of emigration and returnees. 


\section{Who Could be Trusted and for How Long? The Challenge of Volatile Loyalties of the Experts in Africa}

Growing numbers of Czechoslovak citizens abroad posed a challenge to the highly circumspect state administration. In response to official concerns about the experts' behaviour, various measures were implemented for more effective control and management of their services. The first such state regulation on Czechoslovak citizens' work abroad was made in December 1961 by a document titled The Principles for Selection, Preparation and Assessment of Czechoslovak Experts' Activity Abroad (Zásady pro výběr, prípravu a hodnocení ćinnosti československých pracovniku $v$ zahraničí), which narrowed the group eligible for foreign service to only those absolutely reliable politically-excluding "members of former exploiting classes and their close relatives, representatives of former reactionist parties, workers who betrayed the socialist republic and fled to the West or their relatives living in capitalist countries, [...] workers whose close relatives were sued for anti-State activity". Also ruled out were Czechoslovak citizens who led "bourgeois lifestyles", which was in the eyes of state officials, associated with a bad work ethic, greed, pursuance of personal-meaning material-interests, alcoholism, unprincipled and apolitical action and a disorganized family life. ${ }^{9}$ In contrast, the attributes which qualified experts as trustworthy included "firm morals and character" as they could "solemnly represent our socialist regime by their honourable action and personal lifestyle." ${ }^{10}$ Surprisingly, despite a strong emphasis on moral qualities, membership in the Communist Party was not mandatory. Experts were also required to be experienced professionals who ideally could speak the official language of the country of their stay abroad (in Africa, knowledge of English and French was necessary).

Candidates who successfully passed the selection process were kept in the cadre reserves for service abroad. Eligible experts were apparently divided into several categories, differing in range of imposed political control, expectations about performed loyalty and additional tasks. For instance, experts dispatched through the multilateral system of assistance were subject to international law, which profoundly limited the Czechoslovak authorities' power to supervise and organize their actions. This challenge of divided loyalties of experts and official representatives in the United Nation (UN) system was touched on in The Report of the Preparatory Commission of the United Nations issued in 1945, which classified serving the UN as a "higher interest," superior to more narrow national interests and prejudices. ${ }^{11}$ The first Standards of Conduct for International Civil Service drafted in 1954 ascribed "international loyalty" to UN staff, but at the same time acknowledged that "international and national loyalties may conflict", and compelled governments and organizations not to force experts to choose between them.

The activities and duties of experts in the UN system were thus regulated by separate statutes, which also prescribed a general strategy towards particular international organizations.

8 Národní archiv České republiky (NA ČR), fond (f.) Ústřední výbor Komunistické strany Československa (ÚV KSČ), Antonín Novotný - zahraničí, inventární číslo (inv. č.) Ministerstvo zahraničních věcí (MZV) - činnost Zastupitelských uřadů (ZÚ) v ČSSR a v zahraničí, kartón (k.) 3, case: Zásady pro činnost čs. pracovníků v zahraničí, Prague, 2. December 1961.

9 Ibid.

10 Ibid.

11 United Nations Digital Library, Report of the Preparatory Commission of the United Nations, PC/20, 23. December , 1945, Chapter 8, $\$ 4$. 
The first document of this kind was prepared by the Ministry of Foreign Affairs (MZV), headed by Václav David and endorsed by the UVV KSČ in March 1963, under the title The Positioning and Management of Czechoslovak Experts in the Secretariats of International organizations (Umístňování a rízení čs. pracovníků $v$ sekretariátech mezinárodních organizaci). ${ }^{12}$ The main concern of this document, however, was not exactly to question the international loyalty of experts, but rather to regulate their income by proposing extra taxes-for some, this meant up to $70 \%$ of their salary. The authors assumed that this income from payroll deductions could then be transferred to the state budget.

Nevertheless, the question remains as to what extent this proposal was really put into action. According to documents in the State Security Services Archives in Prague, any attempt to impose such payroll deductions on experts based in a multilateral system of assistance usually ended in vain, mainly because Czechoslovak authorities feared that the experts would lodge official complaints to the organization's headquarters, which would then put the Czechoslovak government in a very uncomfortable situation. ${ }^{13}$ Such episodes indicate that the level of trust between the Czechoslovak government and "their" experts in the UN system varied. Other signs even imply that multilateral experts often used their proclaimed adherence to "international loyalty" as an excuse to avoid cooperation with the STB or taking on extra assignments for Czechoslovak foreign policy interests. ${ }^{14}$

The activities of the experts during their tenure were-at least on paper-supervised by the Czechoslovak Permanent Mission to corresponding international organizations or the nearest Czechoslovak embassy (Zastupitelský úrad, ZÜ). Czechoslovak diplomatic representatives demanded a demonstration of loyalty from the experts through various means. Usually, they were asked to collect information about the internal relations of particular organizations, to seek technical documentation from specialized departments or to engage in industrial espionage, etc. Apart from these tasks, the representatives of permanent missions and the ZU were instructed to guide the experts on influencing decision-making within international agencies in such a way that would benefit the Czechoslovak economy. In optimal conditions, experts were expected to lobby for Czechoslovak projects or secure transfer of Czechoslovak commodities and services within particular projects:

Close attention should be paid to those Czechoslovak employees who could push the realization of the organization's action in a way which would be profitable for the Czechoslovak socialist republic (ČSSR), in terms of hard currency profit. This includes the purchase of various raw materials and commodities in the CSSR and appointment of our scientific institutes in charge of research projects, etc. Such opportunities the experts in secretariats of specialized international organizations have particularly, such as the International Atomic Energy Agency, UNESCO, the WHO, etc. ${ }^{15}$

12 NA ČR, f. ÚV KSČ, Antonín Novotný - zahraničí, inv.č. MZV - činnost ČSSR v mezinárodních organizacích, k. 4, case: Činnost československých zástupců v sekretariátech mezinárodních organizací, Prague 14. March 1963.

13 Archiv bezpečnostních složek (Archives of the Security Services, ABS), f. A11: Odbor pro mezinárodní styky, inv. č. 1220, Systém vysílání Československých státních příslušníků do OSN - poznatky, Prague 1970.

14 In 1970, an STB officer in Dar es Salaam reported UNESCO experts' claims for "neutrality" in international relations. See ABS, f. Hlavní správa rozvědky Sboru národní bezpečnosti (SNB) - svazky (I.S - svazky), reg.č. 11690 (arch. č. AS 17630 I.S) - podzväzok reg.č. 11690/326 I.S (arch. č. AS 14626 I.S), Čs. expert na univerzite v Dar es Salaam, without date, ca.1970.

15 NA ČR, f. ÚV KSČ, Antonín Novotný - zahraničí, inv.č. MZV - činnost ČSSR v mezinárodních organizacích, k. 4, case: Činnost československých zástupců v sekretariátech mezinárodních organizací, Prague 14. March 1963. 
The state thus relied on experts for a number of important tasks. This dynamic shows that the experts gained a certain leverage in negotiating with the state power. With trust being mutually beneficial, it is likely that if experts agreed to work in the best interests of the Czechoslovak regime within international affairs, they demanded something in returnusually preservation of their economic privileges. Anytime the Czechoslovak authorities made attempts to disturb this balance of advantages, the experts rebelled and the whole trust network fell apart.

This volatility of cooperation between the experts and the ZÚ is evident in a number of reports prepared by official state correspondents for the MZV. According to these reports, the majority of cases of uncooperative behaviour occurred when Czechoslovak officials attempted to infringe upon the economic privileges of the experts and compel them to pay the extra taxes. A classic example is the situation of Czechoslovak experts in Ghana, whose perpetual disregard for state instructions developed into a recognised issue over the course of the 1960s.

The state correspondent in Accra, the capital of Ghana, "Dvořák", interpreted the experts' defiance as the result of a "long separation from life in Czechoslovakia", something that in his eyes led to "[attempts to set up] private businesses, complaints about salaries and criticism of Polytechna's practices". ${ }^{16}$ As a result, the experts "do not pay the extra taxes from their foreign income to Polytechna, they spend money on whatever they like and ignore Polytechna deputies' urgent warnings." ${ }^{\prime 7}$ A critical situation concerning supply services and inflation in a number of African countries only compounded the problem. For instance, the Czechoslovak state correspondent in Guinea, Bohuslav Málek, complained in 1970 that the combination of increased taxes and high prices of foodstuffs in the specialized shops for international clientele in Guinea resulted in experts struggling to make ends meet. Under such circumstances, many experts were forced to find side work. As an example, it was quite common for Czechoslovak doctors or professors at medical faculties to set up private medical practices. ${ }^{18}$

In the report cited above, "Dvořák" 19 also made several interesting observations about the quality of experts' political preparation, remarking:

The experts who work outside the capital in various parts of the country, often in very isolated places, are badly influenced by the local environment, which negatively affects the results of socialist education in ČSSR. It would be necessary to strengthen the experts' connection with the homeland and improve their political training provided by Polytechna's deputy in Ghana and the ZÚ. ${ }^{20}$

16 Polytechna was one of the Czechoslovak foreign trade corporations established in 1959 as an executive body of the Ministry of Foreign Trade. Their main function was to mediate commercial agreements with foreign states. Specifically, Polytechna was responsible for facilitation, purchase and sale of industrial licences, technical projects, research, development, engineering and consulting services, including technical aid.

17 Archiv Ministerstva zahraničních věcí České republiky (Archives of the Ministry of Foreign Affairs of the Czech republic, AMZV ČR), f. TO - T 1965-1969, Ghana, k. 1, inv. č. 202/211, case 21, Spolupráce ZÚ s experty v II. pololetí 1964, Accra, 8. December 1964.

18 AMZV ČR, f. TO - T 1970-1974, Guinejská republika, k. 1, inv. č. 203/113, case 3, Čs. vědecko-technická pomoc Guinejské republice. Politickohospodářská zpráva č. 9, Conakry 4. December 1970.

19 In this text, code names of STB officers as well as ideo-conspirators are indicated by quotation marks.

20 AMZV ČR, f. TO -T 1965-1969, Ghana, k. 1, inv. č. 202/211, case 21, Spolupráce ZÚ s experty v II. pololetí 1964, Accra, 8. December 1964. 
This falling trust between Czechoslovak authorities and experts working on long-term contracts in remote areas of Africa was also mentioned in the regular evaluation reports issued by state correspondents in the late 1960s. In 1967, the state correspondent in Accra, "Jarošík", reported that communication with experts working outside of Accra was basically reduced to "collecting taxes for Polytechna." ${ }^{21}$ Conversely, the ZÚ maintained regular contact with the experts living in Accra and Kumasi, where the so called stranícke skupiny (clubs that united all Communist party members in a particular town) were established. These displaced party organizations apparently played a crucial role in maintaining cohesion within Czechoslovak communities by organizing social events, such as International Women's Day or New Year's Eve etc., which in effect, facilitated more effective control of communication with persons outside this trusted circle.

The correspondent also expressed serious concerns about the moral qualities of some dispatched experts:

Many incidents proved that the selection and preparation of experts is insufficient, and in some cases irresponsible if not shocking. I am concerned particularly about the political maturity of dispatched employees, their character attributes such as integrity, honesty, diligence and willingness. Many experts not only lack these elementary qualities of individuals and citizens coming from a socialist society, but they excel in greed, jealousy and mammonism, and at every cost. ${ }^{22}$

He complained that experts lacked an "awareness" about their responsibilities towards the ZÚ, refused to pay membership fees to the základní organizace KSČ (the basic organization of the Communist Party of Czechoslovakia, ZO KSČ), did not read the party daily or other Czechoslovak press and completely avoided "communist party life." ${ }^{23}$ It can be concluded that the longer experts stayed abroad, the more inclined they were to "turn native" and become accustomed to a lifestyle incompatible with socialist citizenship. The sense of shared identity as a necessary condition for loyalty seemed to slowly fade away, and with that also the sense of duty towards the Czechoslovak government.

The disintegration of the former trust networks culminated in the years 1968-1969. Liberalizing tendencies of the new Czechoslovak administration led by Alexander Dubček $^{24}$ also had a profound impact on the nature of the social contract between the experts abroad and state authorities. Even prior to this period, Czechoslovak experts in Africa more or less freely travelled to western countries without receiving any formal permission, or at times even despite official refusal. Pars pro toto is a fitting explanation for the experience of a Czechoslovak lecturer at the University of Cape Coast, who in 1967 decided to go on a 3-month study trip to the USA and Canada despite outright

21 AMZV ČR, f. TO - T 1965-1969, Ghana, k. 1, inv. č. 202/211, case 21, Styky ZÚ s československými expertmi v roku 1967 - zpráva, Accra 17. April 1968.

22 Ibid.

23 AMZV ČR, f. TO - T, 1965-1969 Ghana, k. 1, inv. č. 202/211, case 21, Styky ZÚ s československými expertmi v roku 1967 - zpráva, Accra 17. April 1968.

24 The newest publications about Dubček's era and Prague Spring include SCHULZE WESSEL, Martin. Der Prager Frühling. Aufbruch in eine neue Welt. Stuttgart : Reclam Verlag, 2018; MICHÁLEK, Slavomír - LONDÁK, Miroslav et al. Dubček. Bratislava : VEDA, 2018; BISCHOF, Günter - KARNER, Stefan -RUGGENTHALER, Peter (eds.). The Prague Spring and the Warsaw Pact Invasion of Czechoslovakia in 1968. New York : Lexington Books, 2010. 
rejection by the $\mathrm{MZV} .{ }^{25}$ In a letter to the MZV, he argued that many Czechoslovak experts arranged trips to the USA without notifying the embassy. But what makes this case interesting is the MZV's impotent response to the whole incident. It seems that neither the MZV nor any other authority imposed any disciplinary charges or made any attempt to dismiss the rebellious expert from Ghana. However, the relaxation of strict state control was only temporary and the invasion of Warsaw pact troops in $\mathrm{Au}$ gust 1968 initiated a new, fierce debate over the concept of loyalty in socialist Czechoslovakia.

\section{"Consolidation" in the Former Trust Networks after 1968: Party-liners Are the Most Unreliable Communists?}

The liberalizing tendencies in state administration that peaked in 1968 were later severely criticised by the newly elected, "normalized” party leadership led by Gustáv Husák. After the $14^{\text {th }}$ Congress of the KSČ in May 1971, the party functionaries cemented a "firm alliance" with the Soviet Union and other states from the socialist bloc. This also affected the state's strategy of development aid, which should have been centred on "the final goals of socialism" and not merely reduced to pursuing "material advantages." 26

The personnel makeover in the highest ranks of party and government bodies incited a series of "self-criticizing campaigns" against "rightist tendencies" in the state apparatus, with the expert service system particularly severely hit by these "crusades" against antisocialist deviations. The new leadership of the MZV, headed by Bohuslav Chňoupek, accused the former administration of a rather benevolent selection, which "did not sufficiently consider the political criteria." ${ }^{27}$ The consequences of such proceedings fully unfolded in the "critical years" of 1968-1969, when many experts "politically failed and adopted anti-socialist and anti-Soviet attitudes." 28 Tension between the new government and experts dispatched by former leadership culminated in a wave of emigration. Between the years 1968-1969-solely within the bilateral system of contracts-147 Czechoslovak experts emigrated, $18.7 \%$ of the total working in developing countries. ${ }^{29}$

In order to "fix severe deficiencies" in foreign service, the new government tightened regulations concerning work trips abroad. In June 1973, a document called The Agenda for Party Authorization of Foreign Tours of Czechoslovak Citizens (Pořádek pro stranické schvalování zahraničních cest čs. občanů) submitted by a secretary of the UUV KSČ Vasil" Bilak, was ratified..$^{30}$ According to the new statutes, every work trip, whether long- or short-term, must be approved by each level of the pyramidal party structure, from city committees up to the very centre. These measures sought to prevent another "anarchy" in international relations, as was seen in the years 1968-1969 when work trips abroad

25 AMZV CR, f. TO - T 1965-1969, Ghana, Ghana - neoprávněné cesty čs. expertů do zahraničí, Praha, 24. June 1967.

26 NA ČR, f. ÚV KSČ Gustáv Husák, k. 801 - Federální ministerstvo zahraničních věcí, case: Zahraničnopolitická činnost' po 14. zjazde KSČ, Praha 1971.

27 Ibid.

28 AMZV ČR, f. Porady kolegia 1953 - 1989, kniha č. 142, Vedecko-technická spolupráca ČSSR s rozvojovými krajinami. Správa MZV pre poradu kolégia ministra dňa 31. marca 1971.

29 The result measured in 1968, when the highest number of experts (785) worked in developing countries within a bilateral form of assistance. Ibid.

30 NA ČR, f. KSČ-ÚV, Praha - Předsednictvo 1971 - 1976 (02/1), sv. 83, archivní jednotka (arch. j.) 79/5, Pořádek pro stranické schvalování zahraničních cest čs. občanů, Prague, 1. June1973. 
became "an important platform for antisocialist and rightist forces." ${ }^{31}$ According to this document, the origin of such "anarchy" was the Presidium's decree from May 1968, which virtually allowed unconditional travel to capitalist countries as well as visits from these countries to Czechoslovakia. This practice swiftly ended in April 1969 and soon after in 1970, a Commission for the regulation of foreign relations was established. The Commission's activities considerably decreased the volume of travel abroad, from 80 thousand in 1969 to 7139 in 1970 (aside from recreational tours). ${ }^{32}$

The consolidation process of Czechoslovak communities in Africa led to a total disintegration of former trust networks between the experts and STB officers. It is worth noting that a vast majority of former ideo-conspirators ${ }^{33}$ and diplomats who were sent abroad in the second half of 1960s openly supported Dubček's regime and refused to cooperate further with representatives of the STB. The case of Ján Šebík serves as a good example. The Czechoslovak ambassador in Giunea since 1965 became a leading figure of the anti-Soviet protests in Conakry. In the aftermath of these demonstrations, an STB officer in Conakry known as "Helan" reported that trust between ideo-conspirators and rezidentura ${ }^{34}$ was destroyed by "conflicting opinions over the developments in the party and society", "distorted conceptions about the work of STB officers home and abroad" and by a general "conviction that the work of our [STB] department is harmful and pointless." 35 "Helan" further noted that the current network of ideo-conspirators "fully politically failed, despite the fact that, for the most part, they were long-time party-liners." 36 The messy situation was exasperated by an instable radio connection, which made communication with headquarters in Prague rather difficult. STB officers were therefore apparently left in the dark about which rules of confidential communication were still valid and which had been discarded.

"Helan" also reported that in Conakry, there was a large group of experts who maintained suspicious contacts with western representatives. The internal sub-networks of trust established and maintained between experts of various nationalities as such became a double-edged sword-necessary for access to confidential information but dreaded for becoming too close with people out of trusted circles. During the post1968 campaigns against "rightist deviations", many experts abroad actually made use of these personal connections with-mostly western-colleagues and diplomats to set the stage for emigration. For instance, according to STB reports, a Czechoslovak expert working as an agronomist at the Tanzanian Ministry for Lands and Water Development known as A. K. used his contacts with the West-German ambassador to emigrate to Vienna and later to Australia. ${ }^{37}$

31 Ibid.

32 Ibid.

33 Originally in Czech "ideo-spolupracovník" - in STB jargon, the lowest category of agents/conspirators.

34 The STB field office or group on foreign territory, which guided a wide range of activities encompassed in the "struggle against the imperialist intelligence". Its operations included collection of information on developments in international affairs and industrial espionage or surveillance of Czechoslovak expatriates.

35 ABS, f. Hlavní správa rozvědky SNB - svazky (I.S. - svazky)sv. č. 11179/116, Zpráva o bezpečnostní situaci na ZÚ KONAKRY, 25. June1969.

36 ABS, f. Hlavní správa rozvědky SNB - svazky (I.S - svazky), sv. č. 11179/116, Situace v čs. kolonii - zpráva, Conakry, 28. January 1969.

37 ABS, f. Hlavní správa rozvědky SNB - svazky (I.S. - svazky), sv. č. 1169/122, Emigrace čs. expertů v Tanzanii, Dar es Salaam, 15. October 1971. 
In response to such reports, the government enacted decree no. 238 in 1973, which ordered all experts who "politically failed" to be dismissed and immediately terminated all international contracts longer than 5 years. ${ }^{38}$ By this logic, any person who had spent more than 5 years abroad was simply expelled from the trusted circle, particularly when their tenure overlapped with the years 1968-69. During the next few years, existing expert networks were quite effectively purged of all "anti-socialist elements." The situation in Czechoslovak communities subsequently cooled down after the forced dismissal or emigration of the most insurgent individuals, and those who were lucky enough to keep their positions stopped openly voicing political opinions. ${ }^{39}$

The next part shows, however, that many experts tried to make use of their wide personal networks to restore the "disturbed trust" of party authorities and gain support for their own interests.

\section{Case studies}

As mentioned above, experts were divided into "experts in key positions" and "the rest", who differed in the degree of trust party authorities endowed them as well as in the level of loyalty that was expected in return. The first group was comprised of ministerial advisers, employees of UNESCO departments, scientists and managers in scientific institutions and industrial companies. The second, mostly of technicians and mid-rank employees. This division was rather logical—the "experts in key positions" regularly met with important social figures and actively participated in debates with significant international impact. Thereby it could be assumed that Czechoslovak authorities were extremely concerned about the credibility of experts sent to high-ranking positions to ensure full support and cooperation in the strategic sectors of foreign policy. From the other side, successful candidates enjoyed a number of privileges, at least in the 1960sthey could promote their research internationally, consult with other experts in their field, have access to literature and laboratory equipment unattainable in Czechoslovakia that time, integrate into internationally-sponsored projects, improve language abilities and boost career prospects. That being the case, what were the loyalty-markers that determined if experts were sent or stayed abroad and how was this "trust" exercised in the long term? The following case studies demonstrate three variants of typical (dis)loyal behaviour by Czechoslovak experts abroad, from a standing party-member, non-party individual and former party-member.

\section{Case I: Reliable Party-Liner}

The first look into the process of trust-building between experts and authorities comes from the story of O. J., a senior assistant at the Faculty of Electrical Engineering at the Czech Technical University in Prague (ČVUT). After a series of Czechoslovak-

38 Nevertheless, archival sources indicate that the withdrawal of the experts rarely happened before the official expiration of their tenure. Or rather, the official request for their immediate return to the CSSR was delivered but simply ignored. This is probably the reason why many experts integrated in development projects backed by the UN emigrated as late as 1971-1975. By 1970, Czechoslovak authorities registered only eight cases of emigration among the experts involved in multilateral system, though by the end of 1973, the number increased to 25. NA ČR, f. KSČ-ÚV 1945 - 1989, Praha - Předsednictvo 1971 - 1976 (02/1), sv. 73, arch. j. 69/8, Čs. personálna politika voči sekretariátom medzinárodných organizácí, 1973.

39 ABS, f. Hlavní správa rozvědky SNB - svazky (I.S - svazky), sv. č. 11179/116, Morálněpolitická situace v čs. kolonii - zpráva, Conakry, 1. December 1969. 
Ghanaian bilateral negotiations in 1964, he left to take a professorship at the University in Kumasi, Ghana, the largest city in the Ashanti region. The beginnings of O. J's association with the STB stretch back to 1959, when he worked as head of the Commission for Foreign Students at the Faculty of Electrical Engineering. He was evidently also a leader of the faculty's party group as well as a member of the faculty committee of the KSČ. According to a personal review written in 1959 by the head of the faculty, his work with foreign students was highly appreciated, "especially in recent times, when students from the capitalist countries of the Near East came to study here, he is doing wonderful propagandistic work [...]." ${ }^{40}$

O. J. was officially recruited in July 1960 under the code name "Jaroš." His first assignment entailed the personal profiling of Arab students at the ČVUT with the goal of selecting suitable candidates for counter-intelligence tasks. ${ }^{41}$ It seems likely that the good impression "Jaroš" made during his first mission proved his credibility and prompted a successful nomination to the cadre reserves in 1962.

Nonetheless, his position in Ghana initially did not look so favourable. "Jaroš" was assigned to Kumasi, thousands of miles away from the Czechoslovak ZÚ in Accra, which made regular communication with the STB field office rather difficult. During his first two years in Ghana, cooperation with the STB remained irregular and rather unproductive. Things moved forward apparently only on O. J.s own initiative in August 1966, when he personally approached two former officers he knew from his early days at the ČVUT. According to a report from the meeting, O. J. provided information about British radar technology production, which the Ghanaian government was considering purchasing. It turned out that in 1965 "Jaroš", took advantage of his social network at the University in Kumasi and was appointed a member of the official Ghanaian delegation headed to London to negotiate purchase terms. ${ }^{42}$ The Ghanaian authorities seemed to strongly rely on his professional advice. At STB headquarters in Prague, these documents were identified as "interesting and instrumental for intelligence service." ${ }^{43}$ Following this episode, O. J.s cooperation with the rezidentura got a second wind. In December 1966, the STB administration decided to trust him with other missions, mainly profiling western experts and progressive students at the university, also to investigate the political mood among local intelligentsia after the coup détat of Nkrumah's administration in February 1966. ${ }^{44}$

The close contacts he maintained with local elites as well as capitalist colleagues allowed him to relay a lot of confidential information about Ghanaian relations to other African countries-particularly Nigeria-and also about arms treaties with western states. ${ }^{45}$ Throughout the entire sojourn in Ghana, STB officers held his work in high es-

40 ABS, f. Zpravodajská správa Generálního štábu československé lidové armády - svazky (ZS/GŠ - svazky), arch. č. OS-18579 ZSGS.

41 ABS, f. Hlavní správa rozvědky SNB - svazky (I.S - svazky), registrační číslo (reg. č.) 42890 I.S (arch. č. AS11469 I.S), KS MV Praha - Záznam o verbovce, Prague, 26. July 1960.

42 ABS, f. Hlavní správa rozvědky SNB - svazky (I.S - svazky), reg. č. 42890 I.S (arch. č. AS-11469 I.S), Spol. Jaroš zaslání materiálů, 19. September 1966.

43 Ibid.

44 ABS, f. Hlavní správa rozvědky SNB - svazky (I.S - svazky), reg. č. 42890 I.S (arch. č. AS-11469 I.S), O. J. pokyn ke kontaktu, Prague, 9. December 1966.

45 ABS, f. Hlavní správa rozvědky SNB - svazky (I.S - svazky), reg. č. 42890 I.S (arch. č. AS-11469 I.S), Schůze s I. S. Jaroš - záznam, Accra 24. January 1968. 
teem. It is also worth noting that from 1970 until his departure, he functioned as leader of the party group in Kumasi.

Unfortunately, available documents are quiet about O. J's political attitudes towards the invasion by Soviet troops and the aftermath, which found him still in Kumasi. What is certain, "Jaroš" survived the post-1968 party purges and after returning, he took up his old position at the Faculty of Electrical Engineering at the ČVUT. In this case, collaboration with the STB proved to be mutually beneficial, allowing him to endure quite a rocky period without any devastating consequences to his professional or private life. As evidence of his unshattered credibility, in the 1970s, the STB were even considering a renewal of cooperation, this time focused on the activities of Chinese diplomatic personnel at their embassy in Prague. This project, however, never materialized officially due to O. J.'s lack of interest to take any form of action in this matter. ${ }^{46}$ Moreover, in 1975 , he resigned from his function as head of the foreign students' committee and so was no longer considered "promising" for the STB investigation.

\section{Case II: Reliable Non-Party Individual}

A different facet of the larger picture can be seen in the story of Czech professor of chemistry at the Slovak Technical University in Bratislava V. Š., who participated in the UNESCO project "Training of secondary school science teachers" for Africa. He spent his first term (1964-1967) in Ghana at the University College of Cape Coast and after successful completion of the mission, was offered another contract, this time at the Faculty of Science at the University of Dar es Salaam in Tanzania. It was during his second tenure in Africa, between the years 1968-1970, when STB officers became interested in him.

According to a brief summary of V. Š.s career development attached to his file, during both terms in Africa, he was accompanied by his wife and young son. In contrast to the prior example, both V. Š. and his wife were non-party. STB records detail his activity only after 1968 so it is impossible to reconstruct the circumstances of his nomination or any motivation for application to the UNESCO post before this time. From the available documents it is observable, however, that after August 1968, he displayed an extraordinary loyalty to the socialist regime. An STB officer in Dar es Salaam (DES) described him as "a mindful citizen of the ČSSR, who understands the political development in our country." ${ }^{47}$ It is worth noting that V. Š.s cooperation with the STB intensified only in the post-1968 period, before he was utilized only as so-called aktiv. ${ }^{48}$

To make sense of V. Š's activities in the years 1970-1971, is essential to mention that in 1970, he requested an extension of the UNESCO contract, which was submitted in the time when Czechoslovak authorities tended to terminate experts' contracts early rather than to support extension. It thus seems plausible then that V. Š.s mobilized loyalty was

46 He argued that at present, he maintained no contacts with anyone from the Chinese ZÚ. His precise words were that keeping contacts with any foreign ZÚ he "does not consider purposeful, beneficial" and perceived even as "dangerous". ABS, f. Hlavní správa rozvědky SNB - svazky (I.S - svazky), reg. č. 42890 I.S (arch. č. AS-11469 I.S), 1. správa FMV odbor 47 - obnovenie spolupráce, Prague, December 1971.

47 ABS, f. Hlavní správa rozvědky SNB - svazky (I.S - svazky), reg.č. 11690 (arch. č. AS 17630 I.S) - podzväzok reg. č. 11690/326 I.S (arch. č. AS 14626 I.S).

48 Jargon for "the unwitting source". Usually approached by an I.S or STB officer, unaware of their affiliation with the MV structures. 
motivated by an effort to prove his credibility in exchange for a favourable review of his extension request.

His coordinating officer "Bílek" sent a report to headquarters in Prague in which he openly asked for positive consideration of the application:

[V. $\check{S}$.] strives to be as beneficial for us as possible. In comparison to other experts, even the party-liners, he maintains the most open attitudes towards the ZÚ. He does not argue that as a UNESCO employee, he should keep his neutrality, as some experts do, instead he advocates and appropriately promotes the ČSSR everywhere. Therefore, we also asked our headquarters to support his request for extension of the contract with the university in DES for one more year. ${ }^{49}$

However, things in Prague were apparently moving very slowly and therefore "Bílek" decided to urge the whole matter a little further by sending another letter, this time backed by a recommendation written by the chief of the $3^{\text {rd }}$ department of the First Directory of the Ministry of Interior (MV), Miloslav Kachva. In this second letter, V. Š.s exemplary behaviour in the months following the August 1968 was highlighted:

Although both prof. V. ̌́. and his wife are not party members, they have positive relations to work, to promotion of our homeland and to the friendship with the Soviet Union. After August 1968, they often met with professors from socialist countries at the university and with the ambassadors of socialist states at my place..$^{50}$

The report also implied that V. Š. informed the STB office in Tanzania about the activities of western experts and lecturers at the university. Additionally, "Bílek" underlined the economic potential of his position as a government advisor, especially in regard to the evaluation of Tanzanian kaolin reserves. ${ }^{51}$ After this intervention, the Ministry of Interior of SSR granted permission for a contract extension and V.Š. was allowed to stay in Tanzania until 1971.

The V. ̌́. case illustrates how experts learned to make use of their older trust networks and personal connections in the Tanzanian government to re-build credibility in the eyes of the new leadership. Typical strategies included references to proper, pro-Soviet attitudes after the invasion of Soviet troops and a sense of patriotic duty towards Czechoslovakia. However, the crucial factor in restoring a "pragmatic" trust seemed to be the economic potential of each expert's position. It appears that state organizations believed that V. Ś., as a government advisor responsible for the evaluation of natural resources, could influence decision-making for Czechoslovakia's benefit. His loyalty was proven during the international project tender for a ceramic factory in Tanzania. After receiving the list of project proposals, he promised to highlight the advantages of the Czechoslovak offer and agreed to pass competing projects on to Czechoslovak authorities for further investigation. ${ }^{52}$

49 ABS, f. Hlavní správa rozvědky SNB - svazky (I.S - svazky), reg. č. 11690 (arch. č. AS 17630 I.S) - podzväzok reg.č. 11690/326 I.S (arch. č. AS 14626 I.S), Čs. expert nauniversite v Dar es Salaam, without date, ca. 1970.

50 ABS, f. Hlavní správa rozvědky SNB - svazky (I.S - svazky), reg.č. 11690 (arch. č. AS 17630 I.S) - podzväzok reg.č. 11690/326 I.S (arch. č. AS 14626 I.S), S. - aktiv, 1. June 1970.

51 Ibid.

52 Ibid., without date, ca. 1970. 
Despite a rather fruitful cooperation, when V.Š. received an offer from UNESCO to participate in another project in January 1971, the Czechoslovak authorities refused another contract extension and V. S.'s official tenure in Tanzania thus expired June 14, 1971. The final evaluation report issued by STB officer "Tichý" in May 1971 described him as a "dutiful citizen of the ČSSR who was well-aware of his moral duties towards his homeland. During his stay in Tanzania, he served as an excellent example for other experts and his attitude to the ZÚ was very good." 53 "Tichý" fully recommended V. Š. for further cooperation during his next stay abroad, but despite the good references, available documents imply that after returning to Czechoslovakia, V. Š.s activities in Tanzania were subjected to several screenings. It remains unclear which part of the profile put his loyalty in question, though, spending three consecutive terms as a UNESCO expert was perhaps too long, even for an accredited co-operator. Although V. Ś. initially struggled to find a proper job back in Czechoslovakia, he eventually took a research position in one of the Czechoslovak chemical companies. While such a move could be viewed as a downturn in his career, he did manage to stay in the field and was not prosecuted further. The strategic loyalty exhibited during the last two years of his stay in Tanzania perhaps prevented further damage. To his enduring credibility, unlike many other Czechoslovak experts in Tanzania, he never attempted to emigrate. The fact that in 1973, he was dispatched as an expert to the construction of a cement plant in Yugoslavia demonstrates clearly that V. S.'s political integrity was no longer questioned. $^{54}$

\section{Case IV: A Renegade}

A final account which illustrates the differing trajectories of Czechoslovak experts in Africa is the career of Slovak law expert V. Z. Originally a senior economist at the State planning commission of the Slovak National Council in Bratislava, he was officially recruited to the Intelligence Services as an ideo-conspirator in August 1965 in response to his appointment as advisor at the Guinean Ministry of Economic Development and Planning. ${ }^{55}$ Besides professional qualifications, it was his family history which apparently helped establish credibility. His father was a member of the early generation of principled communists who joined the Communist Party of Slovakia (KSS) in the interwar period, ${ }^{56}$ though, his mother and wife ostensibly did not have party membership. V. Z. himself joined the party only in 1956.

V. Z. was recruited within the framework of "economic affairs," which predominantly investigated the attempts of non-aligned and capitalist lobbyists to infiltrate into the Guinean national economy. In secret police documents, he appears under the code name "Králík." The list of V. Z.'s investigative reports on Guinean economic relations detailed for the Czechoslovak rezidentura in Conakry is quite long and very precise. It

53 ABS, f. Hlavní správa rozvědky SNB - svazky (I.S - svazky), reg. č. 11690 (arch. č. AS 17630 I.S) - podzväzok reg.č. 11690/326 I.S (arch. č. AS 14626 I.S), Vyhodnotenie spolupráce s aktivom Bera, Dar es Salaam, 30. May 1971.

54 ABS, f. Hlavní správa rozvědky SNB - svazky (I.S - svazky), reg. č. 11690 (arch. č. AS 17630 I.S) - podzväzok reg. č. 11690/326 I.S (arch. č. AS 14626 I.S), 1. správa FMV, odbor 47 - Vyhodnotenie spolupráce, 29. May 1974.

55 ABS, f. Hlavní správa rozvědky SNB - svazky (I.S - svazky), reg. č. 44261 I.S (AS-13161 I.S), Dr. V. Z. - získání ke spolupráci, Prague 28. April 1965.

56 ABS, f. Hlavní správa rozvědky SNB - svazky (I.S - svazky), reg. č. 44261 I.S (AS-13161 I.S), Záznam o verbovacom pohovore - Memorandum, Prague, 11. August 1965. 
appears that "Králík" monitored the deliveries of food and technical supplies granted to the Guinean government, the spending of foreign development loans, business agreements and technical aid provided by western donors. Throughout the entire period, he was described as a very reliable co-operator.

A turning point in the prosperous cooperation between V. Z. and Czechoslovak authorities came with the inauguration of Alexander Dubček's administration in January 1968. "Králík", who was characterized by his coordinating STB officer "Pecháček" as "Slovak-federalist", apparently very carefully monitored the current political developments in the ČSSR, particularly the problem of Czech-Slovak national justification. ${ }^{57}$ In this period, "Pecháček" noticed a subtle change in "Králík's" behaviour, especially his reluctance to submit promised economic analyses. "Pecháček" attributed this shift in attitude towards cooperation with the rezidentura to the "current psychosis spreading from the ČSSR", which made "Králík" anxious about the potential revelation of his collaboration with the STB, possibly discrediting a promising career in the UN. ${ }^{58}$

A tendency to limit meetings with STB officers intensified after the invasion of Soviet troops in August 1968. The event mobilized a number of violent protests in Czechoslovak communities across all of Africa, which openly criticised the Soviet leaders and the dismissal of Dubček's administration. ${ }^{59}$ According to reports on the "moral and political situation in the Czechoslovak community in Conakry" issued between autumn 1968 and summer 1969, V. Z. was apparently actively engaged in the activities of a "rightist group." However, initially it seemed that his role in the anti-Soviet protests was rather rank-and-file, with the primary responsibility placed on Czechoslovak chargé d'affaires Jan Šebík. The first report very discretely pointing out flaws in V. Z.'s political behaviour after August 1968 was submitted in May 1969. "Pecháček" remarked that V. Z.s performance in the "rightists' group" at the Czechoslovak ZU' "left unpleasant imprints on the mutual relations between 'Králík' and rezidentura. Although Kralík understood the errors of his behaviour, he still did not restore his good relations to coordinating officer." ${ }^{\text {" }}$

Interestingly, despite these "unpleasant imprints", it seems that "Králík" continued cooperation with the rezidentura even after the anti-Soviet protests, submitting a number of interesting analyses concerning Guinean economic relations. It seems even that during 1969, he restarted his own initiative, apparently in an effort to prove an ongoing loyalty to STB headquarters. His endeavours eventually bore fruit as in 1969, he spent three weeks in the USA and Canada without arousing the least hint of suspicion among the MV's officers. Moreover, at the beginning of 1969 he managed to gain support for

57 The federalization of the Republic where the Slovaks would acquire a tantamount position to Czechs.

58 ABS, f. Hlavní správa rozvědky SNB - svazky (I.S - svazky), reg. č. 44261 I.S (AS-13161 I.S), I. zpráva MV 4. odbor, Schůzka s IS KRÁLÍKEM 29. April 1968. His change of attitude towards the STB is probably related to discussions about reforming the position, focus and legal status of the Czechoslovak Intelligence, which took place in Czechoslovakia that time. The leading figure of this reform movement was a newly appointed Minister of Interior, Josef Pavel (April 8, 1968). The key reform concerned the separation of the Intelligence Service from the Ministry of Interior, however, the invasion of Warsaw pact troops in August 21 put an end to whole process. Pavel himself resigned by the end of August, replaced by the conservative Jan Pelnař. For more on the reform movement in Czechoslovak intelligence see KAŇÁK, Petr - SVOŘÁKOVÁ, Jiřina - JUROVÁ, Zdeňka. Československá rozvědka a Pražské Jaro. Praha : ÚSTR, 2016.

59 The subsequent purges in personnel of the MV also affected "Králík"s former coordinating officer "Pecháček", who was dismissed from Conakry in 1969.

60 ABS, f. Hlavní správa rozvědky SNB - svazky (I.S - svazky), reg. č. 44261 I.S (AS-13161 I.S), I. zpráva MV 4. odbor, Vyhodnocení spolupráce s ideospolupracovníkem „Králíkem“, Prague, 4. May 1969. 
relocation to the UN contract system and secure a nomination as head of the ZO KSČ in Conakry. It appears that his leading role in the anti-Soviet protests was fully disclosed only after withdrawal of his former coordinating officer "Pecháček" from Guinea in summer 1969.

A newly installed STB officer known as "Chmelař" identified him as the main orchestrator of anti-Soviet actions, which accelerated the decline of V. Z.s trustworthiness. In September 1969, he was forced to leave his position as leader of the ZO KSČ in Conakry and was dismissed from the KSČ. Subsequently, in January 1970, instead of attending an internal interview, he sent a letter to the party committee stating that he was resigning from all political activity and declared an intention to devote his future life to family and work. ${ }^{61}$ In January 1971, he also finished the contract with the UN. The last report from June 1971 on V. Z.'s movement stated that he unexpectedly left Conakry with his wife and son, officially to spend their last holidays abroad in Spain, however, they never returned to the ČSSR. Final reports imply that they immigrated to Switzerland. ${ }^{62}$ Although it is difficult to determine whether V. Z.'s role in the anti-Soviet protests was diminished initially due to his special relationship with the former coordinating officer-in a "we watch each other's back" way-or the need for a scapegoat for the whole action arose only later, it is clear that V. Z.'s strategic networking with the STB allowed him to survive the last two years in Guinea with all the privileges of a UN expert.

\section{Conclusion}

This study explored the dynamics of trust between Czechoslovak state bodies and experts selected for service abroad in Africa. The first section focused on the state expectations of expert service and the understandings of this duty developed by the experts themselves. From the perspective of state officials, the experts were expected to represent the socialist values and system and always act in favour of Czechoslovak commercial interests. At their departure, experts seemed to sign a trust contract with the Czechoslovak government in which both sides had certain duties and advantages. However, this contract began to disintegrate as soon as the state attempted to abuse the experts'-particularly material-privileges. When the balance of advantages started to swing towards the state, experts began to rebel, ignoring instructions, avoiding social events organized by officers at the Czechoslovak ZÚ and refusing to pay extra taxes. The state's ability to mobilize experts' loyalty abroad was thus rather limited, especially when they lived out of the country for too long or their places of work were in remote areas. It is obvious that the farther from the embassy they were, the more difficult it became for Czechoslovak authorities to keep experts' communication with people outside the trusted circle under control.

During their tenure abroad, experts naturally developed relationships with colleagues from capitalist countries as well as from local administrations. Many of them were therefore targeted for cooperation with the STB who sought to exploit these personal networks for Czechoslovak foreign policy interests. Experts thus established trust net-

61 ABS, f. Hlavní správa rozvědky SNB - svazky (I.S - svazky), reg. č. 44261 I.S (AS-13161 I.S), Králík - poznatky k jeho osobě. Conakry, 20. June 1970.

62 ABS, f. Hlavní správa rozvědky SNB - svazky (I.S - svazky), reg. č. 44261 I.S (AS-13161 I.S), Návrh na uložení do archivu, agenturní svazek č. 44261 Krycí jméno KRÁLÎK, Prague 8. December 1971. 
works on various levels - not only with other experts but with their STB coordinating officers as well-which then could be skilfully utilized for their own benefit. The significance of relations between experts and the STB fully unfolded after August 1968 when older loyalties and ties towards representatives of the former administration were broken and experts were forced to learn to manoeuvre their lives around changing circumstances. During the turbulent years of 1968-1969, many experts made use of contacts with western experts and embassies to facilitate emigration. Others intensified cooperation with the STB to emphasise their continuing loyalty. Some cases showed that restoration or development of new trust relationships with the rezidentura had a profound impact on experts' future careers abroad as well as back home. Interestingly, although the political attitude of experts towards the invasion of Warsaw pact troops definitely played a role in deciding whether to keep or dismiss them from foreign service, or rather how quickly this will be done, the economic potential of their international post was also carefully considered. Their collective experience shows us that to survive "at the least unfavourable terms", the experts had to navigate through many layers of loyalties-to the party, family, foreign employers or even former coordinating officers, which often pursued different aims (aspirations to keep well-paid, international jobs, the sense of "patriotic duty" or, conversely, a desire to have nothing to do with a regime that destroyed the advances of the Prague Spring). However, after 1973, whether reliable conspirator or not, virtually a whole generation of experts who were dispatched abroad during the "critical years" was withdrawn from foreign service. The length of time spent abroad and particularly where the "critical years" were spent thus became new criteria for measuring the credibility of candidates for expert service in the next decade. Although some of them, like V. Š., managed to be sent abroad again, it was only after several years back in Czechoslovakia, apparently to make sure they reinternalized the "correct" viewpoints and lifestyles of socialist citizens.

\section{Cite:}

BUZÁSSYOVÁ, Barbora. Building and Testing Trust Within a Socialist Dictatorship: The Case of Czechoslovak Experts in Africa Pre- and Post-1968. In Forum Historiae, 2021, Vol. 15, No. 2, pp. 69-85. ISSN 1337-6861. DOI: https://doi.org/10.31577/forhist.2021.15.2.6

Barbora Buzássyová

Historický ústav SAV

P. O. Box 198, Klemensova 19

81499 Bratislava

email: barbora.buzassyova@savba.sk

https://orcid.org/0000-0002-8014-2214 